December 2020

\title{
Book Review: Public Library Collections in the Balance: Censorship, Inclusivity, and Truth, Jennifer Downey
}

Carrie E. Kitzmiller

San Jose State University, carriekitz@gmail.com

Follow this and additional works at: https://scholarworks.sjsu.edu/ischoolsrj

Part of the Archival Science Commons, Cataloging and Metadata Commons, Collection Development and Management Commons, Information Literacy Commons, Museum Studies Commons, Scholarly Communication Commons, and the Scholarly Publishing Commons

Acknowledgements

I thank Professor Johanna Tunon for her encouragement to review Public Library Collections in the Balance.

\section{Recommended Citation}

Kitzmiller, C. E. (2020). Book Review: Public Library Collections in the Balance: Censorship, Inclusivity, and Truth, Jennifer Downey. School of Information Student Research Journal, 10(2). https://doi.org/10.31979/ 2575-2499.100204 Retrieved from https://scholarworks.sjsu.edu/ischoolsrj/vol10/iss2/4

This article is brought to you by the open access Journals at SJSU ScholarWorks. It has been accepted for inclusion in School of Information Student Research Journal by an authorized administrator of SJSU ScholarWorks. For more information, please contact scholarworks@sjsu.edu. 


\section{Book Review: Public Library Collections in the Balance: Censorship, Inclusivity, and Truth, Jennifer Downey}

\section{Keywords}

collection management, diversity, intellectual freedom, censorship

\section{Acknowledgements}

I thank Professor Johanna Tunon for her encouragement to review Public Library Collections in the Balance.

About Author

Carrie Kitzmiller graduated with her MLIS from San Jose State University in May of 2020. She is currently working as a Population Health Specialist for a nonprofit healthcare organization. 


\section{Downey, J. (2017). Public library collections in the balance: Censorship, inclusivity, and truth. Libraries Unlimited.}

There are 59 Library and Information Science graduate programs in the United States that are accredited by the American Library Association (ALA), and fewer than half offer courses that center around the issues of censorship and intellectual freedom. If such courses are available, they are offered as electives, rather than the core courses that author Downey believes they should be. Her stated purpose in writing Public Library Collections in the Balance: Censorship, Inclusivity, and Truth is to fill that gap and to serve as an impetus for contemplation and conversation around issues with which public librarians will inevitably be confronted.

Author Downey is well-positioned to write on this topic. She currently works as a reference librarian in Redlands, California. She holds a Master of Library and Information Science (MLIS) degree from San Jose State University and has been published in the journals Progressive Librarian and Reference \& User Services Quarterly. Her published work delves into LGBTQ information needs and challenges to materials that are centered on this community. In Public Library Collections in the Balance, she puts her passion for diversity and inclusivity in public libraries at the forefront. She acknowledges that the book will prompt more questions than answers and ends each chapter with a thought-provoking "What Would You Do?" case study. There are no easy answers. Librarians and MLIS students may find themselves contemplating how they would handle the difficult situations that censorship presents.

Downey begins with the history of American public library censorship. In the early years of the public library system and until the 1930s, censorship, or at least careful selection based on value rather than public demand, was seen as one of the basic duties of the public librarian. It was not until the controversy over Steinbeck's The Grapes of Wrath that the ALA finally determined that access would be a core principle of the profession. Downey gives a good overview of advances in intellectual freedom from that point on, including the adoption of the Library Bill of Rights, the establishment of the Office of Intellectual Freedom, and the fight over the Children's Internet Protection Act (CIPA) of 2003. This section serves as a good foundation for the information in the following chapters.

The next section deals with what types of public library materials are frequently challenged and the reasons. Downey gives a very good explanation of the concept of in loco parentis; then delineates the ALA's stance on the intellectual freedom and first amendment rights of minors. It should be noted that this concept applies to school librarians but not to public librarians. There is a section explaining the dangers of putting quality, content, or warnings labels on library materials and restricting access to items based on content or age of the library user. The author also examines the connection between challenges and the racial, ethnic, sexual, and gender identities of the characters within the challenged materials.

Downey gives the topic of CIPA and internet filtering in public libraries a chapter of its own. The section provides an excellent explanation of why some people feel it is imperative to filter the internet in public libraries, the downside of internet filtering, its effects on economically challenged patrons with no internet access in the home, and the financial reasons why so many public libraries feel they have no choice but to filter. The author shares clear guidelines on internet policy, maximizing information access, and the possible inherent biases present in commercial filtering software.

In the fourth chapter, "Media Matters," the author discusses the way motion picture and video game ratings are often used in public libraries to deny access to minors. The issue of "juvenile- 
only" library cards is examined. While Downey acknowledges the reasons, some public libraries have for using such age-related distinctions, she also gives the ALA position that having such a policy constitutes censorship.

After these preliminary chapters that lay out the current issues with censorship and intellectual freedom in public libraries, Downey gets down to more practical matters. The second half of the book contains valuable insight and information for those working in public libraries and those who plan to in the future. Her instruction on how to prevent and prepare for challenges is essential. The author gives librarians step-by-step information to create a strong collection development policy, staff training to deal with patrons issuing a complaint, and access to professional resources dealing with challenges.

Downey continues with a section on community analysis with regard to collection development. Her warning that community analysis can often lead to collections geared solely toward the demographic majority of a user group is timely and important. She exhorts librarians to continue to assess their community and to take the time to get to know the minority populations and subgroups in order to ensure that their information needs are also being met.

The next section addresses the tricky topic of self-censorship by librarians. Downey provides a clear distinction between selection and self-censorship, explaining that the latter is when a librarian seeks out reasons to exclude certain materials. She acknowledges the reasons why many librarians engage in self-censorship: the desire to avoid complaints and challenges, personal discomfort with subject matter, and/or fear of judgment. The necessity of confronting one's personal biases, having a strong and detailed collection development policy, and training to support library staff is addressed to help diminish self-censorship. Downey asserts the importance of library staff feeling supported in their collection development policies and decisions, which will lead to more confidence and less self-censorship.

In chapter eight, Downey examines the debate between quality and demand in library collections, especially with regard to controversial and conspiracy-driven material. She weighs the issue of giving library patrons access to the materials they want, while also examining the necessity of creating diverse, inclusive collections.

The final chapter gives public library staff and administrators clear and concise advice on what to do when the library receives a complaint or a challenge. She discusses the four levels of complaints and/or challenges: expressions of concern, written grievances, public attacks, and calls for censorship. This chapter contains vital information for librarians who will almost inevitably be faced with these types of scenarios at some point in their careers. The author explains what a review process should look like after a complaint or challenge has been made, how to prepare for and conduct a hearing on a challenged item, and how to communicate final decisions to the complainant and the public at large. She gives librarians practical advice on remaining calm, avoiding defensiveness, and using active listening when dealing with contentious patrons. She concludes with instructions on requesting assistance from the ALA Office of Intellectual Freedom. Downey's epilogue looks to the future, especially with the recent trend toward more censorship and conservative challenges. This final section exhorts librarians to adhere to the Library Bill of Rights and the Freedom to Read statement, to keep the focus on equity of access, and to continue their own personal education with regard to diversity and inclusivity in public library collections. The two appendixes to the volume contain valuable source lists of where collection developers can find LGBTQ-friendly and diverse books from small and alternative presses.

While Downey does not address the philosophical or theoretical issues surrounding censorship and diversity, this book is an extremely valuable resource for public librarians and 
library science students. If public libraries are to fulfill their mandate to serve the entirety of their communities, having diverse, inclusive collections is essential. Public Library Collections in the Balance gives librarians a practical guide for a strong collection development policy and addressing the complaints and challenges that too often follow when embracing diversity. While Downey's book gives librarians a firm foundation on racial, ethnic, gender, and sexual diversity, future research should include an examination of diversity in ability and how to address the needs of patrons with disabilities.

\section{Reference}

Downey, J. (2017). Public library collections in the balance: Censorship, inclusivity, and truth. Libraries Unlimited. 